\title{
Source Headwaters Update: Presidential Beginnings
}

Rusty Juban, Southeastern Louisiana University, USA

Michael C. Budden, Southeastern Louisiana University, USA

Connie Budden, Southeastern Louisiana University, USA

Dawn Wallace, Southeastern Louisiana University, USA

\begin{abstract}
Presidents of higher education institutions are a major source of vision and direction for their respective universities. Established research has shown that a variety of demographic, psychographic and personal characteristics may impact one's thoughts and actions. Undoubtedly, for university presidents, their educational background and the source of their terminal degree play roles in their abilities to lead and in developing their visions. For this paper, we examined the educational background of public university presidents to determine the degree of homogeneity across institutions. The question we seek to address is if vision and leadership are overly influenced by a common educational background with little diversity in source and field of terminal degree.
\end{abstract}

Keywords: Higher Education; Leadership; Diversity; University Presidents

\section{INTRODUCTION}

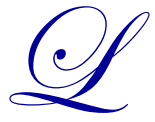
eadership plays an important role in any formal endeavor. Leadership, or getting people to work together to achieve a common goal, serves as a basis for the advancement of any organization's mission (Budden, Budden and Baraya 2007). In education, the mission of the university is the time honored tradition of scholarship and scientific inquiry. But as budgetary issues and educational innovation are changing the landscape of the learning environment, the question arises as to how these demands and constraints are changing the face of university leaders. If leadership is crucial to the advancement of higher education, then the source, or headwaters of such leadership plays a role in determining the effectiveness of higher education leaders and even how university missions are developed and approached. Determining the headwaters of higher education leadership may shed light on educational missions and directions and is the purpose of this paper.

In 2007-2008 a study of the diverse backgrounds of university presidents was conducted and reported (Wallace, et al 2009). An update to that study concerning the situation of women and minorities was reported in 2014 (Wallace, et al 2014). This is a report of the latest data relative to this longitudinal study and specifically seeks to identify those universities and fields of study that serve as the headwaters of university presidents.

As reported in Wallace et al (2014) women now account for slightly more than one-half of all doctorates awarded. Also, the numbers of African-Americans and Hispanics counted among university presidents have both increased from 2007/2008 to 2012/2013. While the race demographic, or surface-level diversity, of the leader is interesting and of significance, it was felt the educational headwaters of presidents would provide additional insight into the underpinnings of higher education. It is this deeper level of diversity, connected to educational backgrounds and level of attainment that have profound impacts on the way leaders communicate, negotiate and set goals (Shropshire, 2010). Extensive research supports the concept that less diversity in the backgrounds of CEOs results in greater imitation in decision-making (Krattz, 1998). In addition, Bantel (1993) and Erhardt, et al. (2003) examination of corporate boards found that those with greater heterogeneity were more likely to be innovate, a quality desperately needed in today's changing educational environment. 


\section{METHODOLOGY}

This research is a continuation and update of a longitudinal study of US universities begun by Wallace et al, 2009. For this study concerning educational background of university presidents, the majority of data was obtained from university websites during spring and summer 2014. In those instances where the desired background information of presidents was unavailable through university websites, emails were sent directly to the president asking for clarification details.

Among the information sought was the educational background and university (or universities) attended. Of specific interest was the highest degree received, the educational field of that degree and the university from which the degree was awarded.

\section{FINDINGS}

A large majority (78\%) of the 390 presidents for which information was available, have obtained a Ph.D. The finding that a majority of university presidents in the US possess research doctorates will not surprise many. Perhaps surprisingly, JD degrees ranked second among the degrees held by presidents (see Table 1).

Table 1. Highest Degrees Earned by Presidents

\begin{tabular}{|c|c|c|}
\hline & Degree & Number \\
\hline Ph.D & & 303 \\
\hline JD & & 37 \\
\hline MD & & 13 \\
\hline MA & & 11 \\
\hline Ed.D & & 8 \\
\hline MBA & & 6 \\
\hline DVM & & 3 \\
\hline BA & & 3 \\
\hline MS & & 3 \\
\hline MEd & & 1 \\
\hline DDS & & 1 \\
\hline BS & & 1 \\
\hline
\end{tabular}

The finding that law (JD) accounts for the educational background of more than $9 \%$ of university presidents was somewhat of a surprise to the researchers. However, given today's litigation-prone environment, the numbers of lawyers assuming presidencies may be something of a trend that deserves continued study.

Another finding was that 13 medical doctors (MDs) are university presidents. Since many flagship schools have large medical components and in many cases the medical school component represents a large component of the overall university budget, the presence of a medical doctor as the president may be justified.

Four university presidents apparently have only a bachelor's degree (BA or BS) as their highest degree earned, while 21 have master's degrees. These 25 presidents represent slightly more than $6 \%$ of the universities investigated. So in short, doctoral degrees of some sort are possessed by slightly more than $93 \%$ of university presidents.

Table 2 displays the fields of study represented by the highest degree earned by the university presidents. 
Table 2. Highest Degree Fields of Study

\begin{tabular}{|c|c|}
\hline Field of Study & $\mathbf{N}$ \\
\hline Public \& Educational Admin. & 52 \\
\hline Law & 37 \\
\hline Engineering & 31 \\
\hline Chemistry & 23 \\
\hline Government/Politics & 22 \\
\hline Medical/Health & 22 \\
\hline Sociology/Psychology & 22 \\
\hline Science (Other) & 20 \\
\hline Business & 19 \\
\hline Education & 16 \\
\hline History & 16 \\
\hline Economics & 15 \\
\hline English & 15 \\
\hline Physics & 10 \\
\hline Psychology & 10 \\
\hline Agriculture/Horticulture & 9 \\
\hline Communication & 9 \\
\hline Mathematics & 9 \\
\hline Biology & 6 \\
\hline Foreign Language & 4 \\
\hline Geology/Archeology & 4 \\
\hline Computer Science & 3 \\
\hline Kinesiology & 3 \\
\hline Music & 3 \\
\hline Veterinary Medicine & 3 \\
\hline Zoology & 3 \\
\hline Other & 4 \\
\hline
\end{tabular}

Public and educational administration, law, engineering, and chemistry are the top four areas of study found among the highest degrees earned by presidents. Government/politics, medical/health, sociology/psychology, other science, business and education round out the top 10 fields.

The educational field and level of degree may impact management decision-making and style. However, the universities these presidents attended to obtain their highest degree may also play a role in their management decisions. Universities in which presidents earned their highest degrees are displayed in Table 3. 
Table 3. Top 25 Presidential Producers

\begin{tabular}{|l|l|c|}
\hline \multicolumn{1}{|c|}{ Rank } & \multicolumn{1}{|c|}{ University } & Number Produced \\
\hline 1 & Harvard University & 12 \\
\hline 2 & University of California, Berkeley & 9 \\
\hline 3 & University of Michigan & 8 \\
\hline 4 & Indiana University & 8 \\
\hline 4 & Ohio State University & 7 \\
\hline 4 & University of Illinois at Chicago & 7 \\
\hline 5 & University of Wisconsin at Madison & 7 \\
\hline 5 & Cornell University & 7 \\
\hline 5 & Massachusetts Institute of Technology & 7 \\
\hline 5 & University of Chicago & 7 \\
\hline 5 & University of Minnesota & 6 \\
\hline 5 & Yale University & 6 \\
\hline 6 & Michigan State University & 6 \\
\hline 6 & University of California at Los Angeles & 6 \\
\hline 6 & University of Illinois at Urbana & 5 \\
\hline 6 & Virginia Polytechnic Institute & 5 \\
\hline 7 & California Institute of Technology & \\
\hline 7 & Florida State University & 5 \\
\hline 7 & Northwestern University & 5 \\
\hline 7 & Pennsylvania State University & 5 \\
\hline 7 & University of Iowa & 5 \\
\hline 7 & University of Pennsylvania & 5 \\
\hline 7 & University of Texas at Austin & 5 \\
\hline 7 & University of Washington & \\
\hline 7 & University of Wisconsin & \\
\hline
\end{tabular}

Ranked number one, Harvard is seen to have produced more current university presidents than any other university. Harvard, Cornell and Yale are the only private schools to be found among the top 25 presidential producers. As can be noted, the top 25 universities that produced presidents of US universities are primarily large, state institutions.

On another note, 12 of these universities also ranked in the top 25 as producers of college of business deans in 2007 (Budden, Budden and Baraya 2007). In that study, deans of business of accredited schools were seen as providing direction and leadership for business education in the United States (2007).

\section{SUMMARY}

University presidents are crucial in setting mission and leading higher education direction. Diversity of a president's educational background, plays a role in their abilities, their priorities and their leadership style and effectiveness. The findings indicate large public institutions and three large private universities comprise the top 25 producers of university presidents. This commonality of educational background represents a fairly homogenous headwaters for university presidents. This leads to an interesting question of how current university presidents view the strategic goal setting process. Do similar and overlapping source of education (our analogy of headwaters) influence a majority of our nation's leading institutions of higher education? If so, does there exist a case of interorganizational imitation based common president backgrounds. This could lead to a case of the same tired solutions being applied across the majority of nation's most prestigious institutions. It is hoped that greater diversity of university presidents as a whole would improve the innovativeness of higher education. While there is a common cry for more diversity in gender and race among higher positions in education, education background should also be viewed as an important diversity variable. 


\section{AUTHOR INFORMATION}

Rusty Juban is an associate professor of management at Southeastern. His areas of interests include leadership, organizational behavior and human resources.

Ms. Connie Budden is an instructor in Management at Southeastern. Her research interests include business education, human resource management, and business sustainability.

Dr. Michael C. Budden is the Benjamin Paul Jones Professor of Retailing and University Ombudsperson at Southeastern. His research interests include ethics, retail control, education, economic impact and business sustainability.

Dr. Dawn Wallace is an associate professor of management at Southeastern. Her research interests include higher education discrimination, business education, communication and student learning through software applications.

\section{REFERENCES}

Bantel, K. (1993). Strategic clarity in banking: Role of top management-team demography. Psychological Reports, 73, 1187-1203.

Budden, M.C., Budden, C.B. and Baraya, (2007). Searching for the source headwaters: Leadership in business education. Proceedings of the 2007 Teaching and Learning Conference, Mazatlan, Mexico. 1-4.

Erhardt, N. L., Werbel, J. D., \& Shrader, C. B. (2003). Board of director diversity and firm financial performance. Corporate Governance: An International Review, 11(2), 102-111.

Kraatz, M. S. (1998) Learning by association? Interorganizational networks and adaptation to environmental change. Academy of Management Journal, 41: 621-643.

Shropshire, C. (2010) The role of the interlocking director and board receptivity in the diffusion of practices. Academy of Management Review, 35: 246-264.

Wallace, D., Budden, M.C., Budden, C.B. and Walker, J. (2009, $2^{\text {nd }}$ Quarter). Perusing the headwaters of diversity among university presidents. Journal of Diversity Management, 4(2), 19-24.

Wallace, D., Budden, M., Juban, R. and Budden, C. (2014, June). Making it to the top: Have women and minorities attained equality as higher education leaders? Journal of Diversity Management, 9(1), 83-87. 
NOTES 